KeMAS 16 (3) (2021) 340-347
Jittp:/journal.unnes.ac.id/nju/index.php/kemas

\title{
Socioeconomic Status in Relation to Stunting and Motor Skill Development of Toddlers in Urban and Rural Areas
}

Syifa F. Syihab ${ }^{\bowtie}$, Mesa Rahmi Stephani, Isti Kumalasari, Adang Suherman

Faculty of Sport and Health Science Education, Universitas Pendidikan Indonesia, Bandung, Indonesia

\section{Article Info}

Article History:

Submitted May 2020

Accepted June 2020

Published March 2021

\section{Keywords:}

children, motor skill

development, socio-

economic status, stunting.

DOI

https://doi.org/10.15294/

kemas.v16i3.24382

\begin{abstract}
The development of child motor skills is closely related to nutritional status. Stunted children generally experience delays in motor development. The objective was to determine the relationship between stunting, socioeconomic status, and children's motor skill development. This research was conducted in 2018 using a cross-sectional method. Respondents were 80 children aged 48-60 months in urban and rural areas of West Java. The researcher used a simple random technique data collection on anthropometric, socioeconomic, and motor skills development. Then it was analyzed using chi-square and Fisher exact methods. The researcher used a simple random technique data collection on anthropometric, socioeconomic, and motor skills development. Then it was analyzed using chi-square and Fisher exact methods. We found that stunting prevalence in rural areas was higher than in urban areas. As much as $30 \%$ of children in rural areas and only $12.5 \%$ of children in urban areas were categorized as stunted. There is no significant association between stunting with the family's socioeconomic status and motor skill development. The weight for the age variable showed a significant association with stunting. Children who are malnourished have a stunting risk of 10.9 times greater than normal children (OR $10.9 \mathrm{p}<0.001)$.
\end{abstract}

\section{Introduction}

Stunting is defined as the height of a person is under -2SD from the standard deviation of Child Growth Standards median (WHO, 2006). Stunted toddler reflects a condition of growth faltering caused by chronic nutritional insufficiency, so they become shorter stature than the age. This condition due to the accumulation of nutritional deficiencies that occur since pregnancy until the children are 24 months old (Bloem, et al., 2013). In 2017, more than half of the world's stunting toddler population was in Asia (55\%), while the remaining $39 \%$ were in Africa. Studies reported 83.6 million stunting toddlers in Asia, whereas the highest was in South Asia (58.7\%). World Health Organization (WHO) mentioned Indonesia was the third country with the highest prevalence stunting in the Southeast
Asia/ South-East Asia Regional (SEAR) region from 2015 until 2017. Indonesia Basic Health Research reported that stunting prevalence in 2007 was $36.8 \%$, the number increased to 35.6 $\%$ in 2010 and reached $37.2 \%$ in 2013 (Pusdatin, 2018). Stunting prevalence decreased to $6.4 \%$ in 2008. Yet still above the global prevalence number of $22.2 \%$ in Indonesia, since WHO determines the definition of nutrition case is less than $20 \%$ (Budiastutik \& Nugraheni, 2018).

Previous studies reported that the prevalence of stunting in most developing countries showed a higher number in rural than in urban areas (Taguri, et al., 2009). In Peru, the national average stunting rate remained unchanged (rural prevalence of stunting stagnated at $40 \%$ while urban stunting dropped from $16 \%$ to $10 \%$ (WHO, 2014). Indonesia showed a similar result, where the stunting 
prevalence in rural areas is higher (45\%) than in urban areas $(35.3 \%)$. Toddlers in rural areas have a risk of stunting 1.27 times greater than toddlers in urban areas (Simbolon, Suryani, \& Yorita, 2019).

There are several short and long terms health risks of stunted children. Short-term impacts include increased incidence of illness and death, delayed cognitive, motor, and verbal developments, and increased health costs (Sari, et al., 2009). Moreover, child development plays a key in the future health, educational success, and economic status (Nyuyen, et al., 2017). Toddlers' motor skill development is a determinant of physical activity in adulthood (Laukkanen, Havu, Saakslahti, \& Taija, 2014).

Several factors are related to the risk of stunting of children. The socioeconomic factor closely affects the family's ability to meet nutritional needs and to access adequate health services for children (Pusdatin, 2018). The study aims to determine the association between stunting with socioeconomic status and motor skill development of children aged 48-60 months in urban and rural areas of West Java Province.

\section{Method}

For this cross-sectional study, the population was toddlers aged 48-60 months from kindergarten and daycare in Bandung city and Ciamis District. The data sampling used the cluster and simple random techniques. The researcher used the cluster method to determine area coverage in the district, sub-district, and village areas. And the random sampling method to determine samples from kindergarten and daycare. Before the research, it required the parents to sign a consent form for their children's involvement. This study involved 80 children aged 48-60 months in the urban and rural areas of West Java. As a representative, samples in urban areas were taken from Bandung City, while for rural areas represented by Ciamis District. The data analysis was conducted using chi-square and Fisher exact methods. Stunting prevalence was the dependent variable. Meanwhile, the independent variables were nutritional status (weight for age and weight for height), socioeconomic status, and motor skill development.
Assessment of children's nutritional status is conducted based on the WHO Child Growth Standard (WHO, 2006). The anthropometric indicators used are weight for age (WAZ), height for age (HAZ), and weight for height (WHZ). WHO's Child Growth Standard median defines Stunting as the proportion of children below -2SD. Before the data collection, the data collectors were firstly trained to ensure that the obtained data were eligible to be analyzed.

Children's motor skill development was measured using Age and Stages Questionnaire, Third Edition (ASQ-3) (Squires \& Bricker, 2009). The parameter chosen in this instrument was the methods for children's gross motor and fine motor skill development measurement. The score limit for the gross motor was 36.27 when the fine motor was 19.82. Children with a total score under the threshold number were categorized as undeveloped.

The researcher uses "Instrument (Scale) for Measuring the Socioeconomic Status of a Family" (Aggarwal, 2005) to measure the socioeconomic status of the children's family. There were 22 questions related to income, number of family members, and level of education, occupation, and property ownership. There were five categories of social status namely poor, lower-middle, uppermiddle, high, and upper-high.

\section{Results and Discussion}

The collected data were analyzed statistically using SPSS for windows version 22. Table 1 shows the descriptive data analysis of children aged 48-60 months, namely: the characteristics respondents, socioeconomic status, and the level of child's motor skills development. Table 1 presents the characteristics of the sample. There were 80 children involved in the study. As many as 40 children were from urban areas, and the remaining amount of 40 children were from rural areas. The number of female and male children was almost the same either in a rural or urban area. In rural areas, the average children's weight is 15.49 with a deviation standard of 2.77. Meanwhile, in urban areas, it is 15.70 with a deviation standard of 2.49. The average height of children in rural areas is 100.65 with a deviation standard of 4.84 , 
and in urban areas, it is 101.36 with a deviation standard of 4.3 .

Several anthropometric parameters determined children's nutritional status, namely: weight, height, and age of the child. Weight descriptive analysis showed that most children in both areas were normal. None of the children from rural areas are overweight. Meanwhile, only $2.5 \%$ of children were overweight in urban areas. The prevalence of underweight children in rural areas showed higher numbers than in urban areas. There are $17.5 \%$ children in the rural, while only $2.5 \%$ in urban areas. Weight for age reflects body mass relative to chronological age. Malnutrition in children reflects the bad nutritional and health status. Globally, malnutrition has contributed to at least half of all the deaths per year in children under five (Liu, et al., 2015). Moreover, children with the mild underweight condition have a higher correlation with mortality than the variance in severe underweight (Bhagowalia, Chen, \& Masters, 2011).

The weight for height data shows that most children had standard weight for height/ body mass index (BMI). The number of wasting children is the same (2.5\%), either in urban or rural areas. The number of normal children in the rural area is $95 \%$, and urban is $97.5 \%$. There is only one case of overweight children who came from rural areas. Low weight for height or wasting is a common way to describe a recent and severe process that has led to significant weight loss, due to acute starvation and/or severe disease. Other research mentioned wasting has higher ratio of mortality hazard than stunting or underweight condition in children (Olofin, et al., 2013).

Based on height for age data, the prevalence of stunting in rural areas was higher than in urban areas. As much as $30 \%$ of children in rural areas and only $12.5 \%$ of children in urban areas were categorized as stunted. Stunting is a physical indicator of chronic malnutrition. It is often associated with the underdevelopment progress of children. A study found that children who lived in rural areas are more likely to be stunted than children from urban areas. Several studies conducted in developing countries, such as Nepal, Bangladesh, Malawi, and Nigeria, have revealed that children settled in rural areas are at higher risk of malnutrition conditions (de Poel, O’Donnell, \& Doorslaer, 2007) (Srinivasan, Zanello, \& Shankar, 2013). In 2018, Indonesia Basic Health Survey reported 30.8 \% stunting cases in Indonesia and $29.9 \%$ in West Java. The number of stunting decreased to $29.2 \%$ in 2019 (Pusdatin, 2018).

Stunting, or short stature for age, is one of the main manifestations of malnutrition (Gillespie \& Hadad, 2003). Stunting reflects prolonged inadequate dietary quality and quantity and frequent infections during childhood (Victora, et al., 2008). In 2008, research showed that there were $32 \%$ or 178 million stunted children in developing countries (Black, et al., 2013). In Indonesia, although the prevalence of stunting among children under five years old has decreased in the past few decades, but the number is still exceeded the WHO recommendations (Semba, et al., 2008). Stunting in early childhood has adverse longterm consequences, including shorter adult height, lower attained schooling, reduced adult income and economic productivity, as well as lower offspring birth weight. Stunted children who gain weight rapidly later in childhood and adolescence are at high risk of chronic nutritional diseases (Victora, et al., 2008).

Family socioeconomic factors were related to stunting prevalence. Economic conditions are nearly associated with the ability to meet nutritious and nutritional intake for pregnant women and toddlers. Other factors such as sanitation and food safety are also known to increase the risk of infectious diseases (Pusdatin, 2018). In 2008, based on data from the Joint Child Malnutrition Estimates, countries with high numbers of upper-middle society can reduce the stunting rate by $64 \%$, while in the country of the lower middle class only reduced about 24\% (UNICEF, 2018). In this study, we tried to find the relation between family socioeconomic status and stunting cases. The socioeconomic status of the children's family was divided into five categories. Namely: poor, lower-middle, upper-middle, high, and upper-high.

This study shows that both in rural and urban areas, most families have upper-middle socioeconomic status. The \%age of families 
with high socioeconomic status is highest in the urban areas. Families with high socioeconomic status in urban areas were $25 \%$. Meanwhile, in rural areas, it was only $12.5 \%$. Lower-middle socioeconomic status in rural areas has a higher prevalence than urban areas. The number of families classified as lower-middle in urban areas is $32.5 \%$. While in rural areas it reaches $37.5 \%$. Children with lower socioeconomic status have a greater risk of stunting in rural areas (Julia, Weissenbruch, Waal, \& Surjono, 2004).

Nutritional adequacy in the First 1000 Days of child life is essential to support child development and adult health. Maternal prenatal nutrition and child nutrition in the first two years of life (1000 days) are crucial factors in neurodevelopment and lifelong mental health. Failure to provide essential nutrients during a critical period of a child's brain development can result in impaired brain function (Schwarzenberg, Georgieff, \& AAP Committee on Nutrition, 2018). Gross motor and fine motor skills are related to the fulfillment of nutritional needs in a child's developmental stages (Putri, Stephani, \& Sumarno, 2020). Therefore, this study also measured the gross motor and fine motor skills development level.

The result found that most children had mastered the fine and gross motor skill growth according to their age. Overall, children's motor skill ability in rural and urban areas shows a good level of development. However, the level of child development in rural areas is higher than in urban areas. The number of developed children in rural areas is $97.5 \%$. While in urban areas, the number is only $90 \%$. Children who live in rural areas are estimated to have adequate open space for playing and doing physical activities (Putri, Stephani, \& Sumarno,

Table 1. Characteristic of Children Aged 48-60 Months in Urban and Rural Area

\begin{tabular}{|c|c|c|c|c|}
\hline \multirow[b]{2}{*}{ Variable } & \multicolumn{2}{|c|}{ Rural } & \multicolumn{2}{|c|}{ Urban } \\
\hline & $\begin{array}{l}\text { Number } \\
(\mathrm{N}=40)\end{array}$ & \%age (\%) & $\begin{array}{l}\text { Number } \\
(\mathrm{N}=40)\end{array}$ & \%age (\%) \\
\hline Age $($ mean \pm SD $)$ & \multicolumn{2}{|c|}{$55.70 \pm 2.77$} & \multicolumn{2}{|c|}{$54.27 \pm 3.50$} \\
\hline Weight $($ mean \pm SD) & \multicolumn{2}{|c|}{$15.49 \pm 2.77$} & \multicolumn{2}{|c|}{$15.70 \pm 2.49$} \\
\hline Height $($ mean \pm SD) & \multicolumn{2}{|c|}{$100.65 \pm 4.84$} & \multicolumn{2}{|c|}{$101.36 \pm 4.30$} \\
\hline \multicolumn{5}{|l|}{ Gender } \\
\hline Male & 18 & 45 & 19 & 47.5 \\
\hline Female & 22 & 55 & 21 & 52.5 \\
\hline \multicolumn{5}{|l|}{ Weight for Age } \\
\hline Under-weight & 7 & 17.5 & 1 & 2.5 \\
\hline Normal & 33 & 82.5 & 38 & 95 \\
\hline Over-weight & 0 & 0 & 1 & 2.5 \\
\hline \multicolumn{5}{|l|}{ Weight for Height } \\
\hline Wasting & 1 & 2.5 & 1 & 2.5 \\
\hline Normal & 38 & 95 & 39 & 97.5 \\
\hline Over-weight & 1 & 2.5 & 0 & 0 \\
\hline \multicolumn{5}{|l|}{ Height for Age } \\
\hline Stunting & 12 & 30 & 5 & 12.5 \\
\hline Normal & 28 & 70 & 35 & 87.5 \\
\hline \multicolumn{5}{|l|}{ Socio-economic Status } \\
\hline Poor & 2 & 5 & 1 & 2.5 \\
\hline Lower-middle & 15 & 37.5 & 13 & 32.5 \\
\hline Upper-middle & 18 & 45 & 14 & 35 \\
\hline High & 5 & 12.5 & 10 & 25 \\
\hline Upper-high & 0 & 0 & 2 & 5 \\
\hline \multicolumn{5}{|l|}{ Motor Skill } \\
\hline Not Developed & 1 & 2.5 & 4 & 10 \\
\hline Developed & 39 & 97.5 & 36 & 90 \\
\hline
\end{tabular}

Source: Research Primary Data, 2018 
Table 2. Association of Identified Variable with Stunting

\begin{tabular}{|c|c|c|c|c|c|c|}
\hline Variable & $\begin{array}{l}\text { Stunting } \\
\text { Number } \\
(\mathrm{N}=17)\end{array}$ & \%age (\%) & $\begin{array}{l}\text { Normal } \\
\text { Number } \\
(\mathrm{N}=63)\end{array}$ & \%age (\%) & OR & P-value \\
\hline \multicolumn{7}{|l|}{ Area } \\
\hline Rural & 12 & 30 & 28 & 70 & 3.0 & $0.056^{*}$ \\
\hline Urban & 5 & 12.5 & 35 & 87.5 & & \\
\hline \multicolumn{7}{|l|}{ Gender } \\
\hline Male & 5 & 13.5 & 32 & 86.5 & 0.4 & $0.117^{\star}$ \\
\hline Female & 12 & 27.9 & 31 & 72.1 & & \\
\hline \multicolumn{7}{|l|}{ Weight for Age } \\
\hline Malnourished & 6 & 66.7 & 3 & 33.3 & 10.9 & $0.001^{\star}$ \\
\hline Normal & 11 & 15.5 & 60 & 84.5 & & \\
\hline \multicolumn{7}{|c|}{ Weight for Height } \\
\hline Wasting & 1 & 33.3 & 2 & 66.7 & 1.9 & $0.517^{\mathrm{a}}$ \\
\hline Normal & 16 & 20.8 & 61 & 79.2 & & \\
\hline \multicolumn{7}{|c|}{ Socio-Economic Status } \\
\hline Lower-middle & 9 & 29 & 22 & 71 & 2.1 & $0.176^{\star}$ \\
\hline Upper-middle & 8 & 16.3 & 41 & 83.7 & & \\
\hline \multicolumn{7}{|l|}{ Motor Skill } \\
\hline Not Developed & 3 & 60 & 2 & 40 & 6.5 & $0.062^{\mathrm{a}}$ \\
\hline Developed & 14 & 18.7 & 61 & 81.3 & & \\
\hline
\end{tabular}

* chi-square test, ${ }^{a}$ Fisher exact test

Source: Research Primary Data, 2018

2020). Besides the genetic potential, the pattern established by environmental factors affects motor development (Venetsanou \& Kambas, 2009). Furthermore, its development in any specific case depends on the affordances and opportunities of the environment, the physical and psychological properties of the child, and the difficulty of the tasks (Kakebeeke, et al., 2017). Early childhood development plays a role in a child's future health, educational success, and economic status (Feinstein \& Duckworth, 2006). Nowadays, over 249 million children are estimated not getting their full growth potential in developing countries, with nearly $53 \%$ (89 million) of these live in South Asia (Black, et al., 2013).

This section relates stunting with socioeconomic status and motor skill development by a bivariable test (Table 2.). We simplify variables with more than two categories into just two. Weight for age variable into two categories, namely malnourished and normal. Weight for height variable into wasting and standard. Socioeconomic variables into lower-middle and upper-middle class. In this research, stunting prevalence was the dependent variable. Meanwhile, the independent variables were nutritional status (weight for age and weight for height), socioeconomic status, and motor skill development.

Data analysis using the Fisher exact test showed that motor skill development and weight for height variables were not related to stunting. Stunted children had a high risk of delayed motor skill development (OR 6.5, p $<0.001)$. Weight for height variable shows no significant association with stunting, but wasted children had a greater risk of stunting (OR 1.9, $\mathrm{p}<0.001)$. Studies showed that toddlers with stunting demonstrated delayed growth and overall development. Moreover, there is a correlation between the history of infectious disease and the family socioeconomic status with stunting prevalence in West Nusa Tenggara (Pacheco, Picauly, \& Sinaga, 2017).

Data analysis using the bivariable chi-square test showed no relation between stunting with area differences, but the odds ratios for stunting (OR 3.0, p < 0.001) were highest for children in rural areas. Nutritional status is often associated with differences in demographic conditions, where children in rural areas had a risk of stunting greater than in urban areas. Many studies also have reported that rural children have a higher risk of becoming wasted than urban children 
(Pasricha \& Biggs, 2010) (Harding, Aguayo, \& Webb, 2018). In this study, gender differences showed a negative association with stunting, but female children have a higher odds ratio for stunting $(0.4 \%, p<0.001)$ compared to male children. This result in line with some studies conducted in West Bengal (Chowdury, Chakraborty, \& Ghosh, 2008) and pre-pubertal children in Indonesia (Julia, Weissenbruch, Waal, \& Surjono, 2004). Socio-economic status also did not show a significant association with stunting. But children from the lower-middle class had a greater risk of stunting (OR 2.1, p $<0.001)$ compared to children from the uppermiddle class. The socio-economic status of the family is known to be associated with children's nutritional status. Children from the uppermiddle class show a lower risk of stunting (32 $\%)$ than children from the lower-middle class (Mzumara, Bwembya, Halwiindi, Mugode, \& Banda, 2018). Family income is one of the socio-economic indicators to fulfill family needs (Reyes, et al., 2004).

Among other variables, only weight for age variable has a significant association with stunting. Analysis results using the chisquare test showed that children with poor nutritional conditions had stunting risk ten times greater than normal children (OR 10.9, $\mathrm{p}<0.001)$. This finding was in line with a study among Malaysian children, where stunting risk was approximately $19 \%$ highest among underweight children and adolescents $(\mathrm{p}=$ 0.030) (Partap , Young, Allotey, Sandhu, \& Reidpath, 2019). Several studies have shown that children with Severe Acute Malnutrition (SAM) have a 12 times greater risk of death than a well-nourished child (Olofin, et al., 2013). Recent studies have shown that children who are wasted and stunted are at a higher risk of death. Compared to those with only one of the two conditions (Myatt, et al., 2018).

\section{Conclusion}

Paragraph Stunting is the impaired child's growth and development due to poor nutrition, repeated infection, and insufficient psychosocial stimulation. The prevalence of stunting in rural areas was higher than in urban areas. $30 \%$ of children in the rural areas and only $12.5 \%$ of children in the urban areas were categorized as stunted. There is no significant association between stunting with socioeconomic status and motor skill development. The weight for age variable showed a significant association with stunting. Children with malnutrition conditions had a stunting risk of 10.9 times greater than normal children (OR $10.9 \mathrm{p}<$ $0.001)$.

\section{Acknowledgments}

The authors are grateful for the Institute for Research and Community Services of Universitas Pendidikan Indonesia and Early Start - University of Wollongong.

\section{References}

Aggarwal, O.B., 2005. A New Instrument (Scale) for Measuring the Socioeconomic Status of A Family: A Preliminary Study. Indian Journal of Community Medicine, 4.

Bhagowalia, P., Chen, S.E., \& Masters, W.A., 2011. Effects and Determinants of Mild Underweight Among Preschool Children Across Countries and Over Time. Economics \& Human Biology, 9(2011), pp.66-77.

Black, R.E., Allen, L.H., Bhutta, Z.A., Caulfield, L.E., Onis, M.D., Ezzati, M., Mathers, C., Rivera, J., 2008. Maternal and Child Undernutrition: Global and Regional Exposures and Health Consequences. Lancet, 731(9608), pp.243260.

Black, R.E., Victora, C.G., Walker, S.P., Bhutta, Z.A., Christian, P., Onis, M.D., Ezzati, M., McGregor, S.G., Katz, J., Martorell, R., \& Uauy, R., 2013. Maternal and Child Undernutrition and Overweight in Lowincome and Middle-income Countries. Lancet, 382(9890), pp.427-451.

Bloem, M.W., Pee, S.D., Hop, L.T., Khan, N.C., Laillou, A., Minarto., Pfanner, R.M., Soekarjo, D., Soekirman., Solon, J.A., Theary, C., \& Wasantwisut, E., 2013. Key Strategies to Further Reduce Stunting in Southeast Asia: Lessons from the ASEAN Countries Workshop. Food and Nutrition Bulletin, 34(2), pp.8-16.

Budiastutik, I., \& Nugraheni, S.A., 2018. Determinants of Stunting in Indonesia: A Review Article. International Journal of Healthcare Research, 2(1), pp.43-49.

Chowdury, S.D., Chakraborty, T., \& Ghosh, T., 2008. Prevalence of Undernutrition in Santal Children of Puruliya District, West Bengal. Indian Pediatrics, 45(1), pp.43-46.

de Poel, E.V., O’Donnell, O., \& Doorslaer, E.V., 
2007. Are Urban Children Really Healthier? Evidence from 47 Developing Countries. Social Science \& Medicine, 65(2007), pp.1986-2003.

Feinstein, L., \& Duckworth, K., 2006. Development in The Early Years: Its Importance for School Performance and Adult Outcomes. London: Centre for Research on the Wider Benefits of Learning Institute of Education.

Gillespie, S., \& Hadad, L., 2003. The Double Burden of Malnutrition in Asia: Causes, Consequences, and Solutions. New Delhi, India: Sage Publication.

Harding, K.L., Aguayo, V.M., \& Webb, P., 2018. Factors Associated with Wasting Among Children Under Five Years Old in South Asia: Implications for action. PLOS ONE, 13(7), pp.1-17.

Julia, M., Weissenbruch, M.V., Waal, H. D.V., \& Surjono, A., 2004. Influence of Socioeconomic Status on the Prevalence of Stunted Growth and Obesity in Prepubertal Indonesian Children. Food and Nutrition Bulletin, 25(4), pp.354-360.

Kakebeeke, T.H., Lanzi, S., Zysset, A.E., Arhab, A., Burgy, N.M., Stuelb, K., Leeger-Aschmann, C.S., Schmutz, E.A., Meyer, A.H., Kriemler, S., Munsch, S., Jenni, O.G., \& Puder, J.J., 2017. Association between Body Composition and Motor Performance in Preschool Children. Obesity Facts, 10(5), pp.420-431.

Laukkanen, A., Havu, M., Saakslahti, A., \& Taija, F., 2014. Relationship between Habitual Physical Activity and Gross Motor Skills is Multifaceted in 5- to 8-year-old Children. Scandinavian Journal of Medicine \& Science in Sports, 24(2), pp.102-110.

Liu, L., Oza, S., Hogan, D., Perin, J., Rudan, I., Lawn, J. E., Cousens, S., Mathers, C., \& Black, R.E., 2015. Global, Regional, and National Causes of Child Mortality in 2000-13, with Projections to Inform Post-2015 Priorities: An Updated Systematic Analysis. Lancet, 385(9966), pp.430-440.

Myatt, M., Khara, T., Schoenbuchner, S., Pietzsch, S., Dolan, C., Lelijveld, N., \& Briend, A., 2018. Children who are Both Wasted and Stunted are Also Underweight and Have a High Risk of Death: A Descriptive Epidemiology of Multiple Anthropometric Deficit. Archives of Public Health, 76(28), pp.1-11.

Mzumara, B., Bwembya, P., Halwiindi, H., Mugode, R., \& Banda, J., 2018. Factors Associated with Stunting Among Children Below Five Years of Age in Zambia: Evidence from the 2014 Zambia Demographic and Health Survey.
BMC Nutrition, 4(51), pp.1-8.

Nyuyen, P.H., DiGirolamo, A.M., Casanova, I.G., Young, M., Kim, N., Martorell, R., \& Ramakrishnan, U., 2017. Influences of Early Child Nutritional Status and Home Learning Environment on Child Development in Vietnam. Maternal and Child Nutrition, 14(1), pp.1-11.

Olofin, I., McDonald, C.M., Ezzati, M., Flaxman, S., Black, R.E., Fawzie, W.W., Caulfield, L.E., \& Danaei, G., 2013. Associations of Suboptimal Growth with All-cause and Cause-specific Mortality in Children Under Five Years: A Pooled Analysis of Ten Prospective Studies. Plos One, 8(5), pp.1-10.

Pacheco, C.D., Picauly, I., \& Sinaga, M., 2017. Health, Food Consumption, Social Economy, and Stunting Incidency in Timor Leste. KEMAS: Jurnal Kesehatan Masyarakat, 13(2), pp.261269.

Partap, U., Young, E.H., Allotey, P., Sandhu, M.S., \& Reidpath, D.D., 2019. Characterization and Correlates of Stunting Among Malaysian Children and Adolescents Aged 6-19 Years. Global Health, Epidemiology and Genomics, 4(4), pp.1-11.

Pasricha, S.R., \& Biggs, B.A., 2010. Undernutrition Among Children in South and South-East Asia. J. Paediatr. Child Health, 46(9), pp.497503.

Priya, B.S.E., 2011. Effects and Determinants of Mild Underweight Among Preschool Children Across Countries and Over Time. Economics \& Human Biology, 9(1), pp.66-77.

Pusdatin., 2018. Situasi Balita Pendek (Stunting) di Indonesia, Buletin Jendela Data dan Informasi Kesehatan. ISSN 2088-270 X. Jakarta: Kementrian Kesehatan Republik Indonesia.

Putri, W., Stephani, M.R., \& Sumarno, G., 2020. Early Childhood Motor Development and Body Mass Index: A Demography Study of Children Aged 4-5 Years in Rural Area. Jurnal Pendidikan Jasmani dan Olahraga, 5(1), pp.1-5.

Reyes, H., Cuevas, R.P., Sandoval, A., Castillo, R., Santos, J.I., Doubova, S.V., \& Gutierrez, G., 2004. The Family as a Determinant of Stunting in Children Living in Conditions of Extreme Poverty: A Case-control Study. BMC Public Health, 4(57), pp.1-10.

Sari, M., Pee, S.D., Bloem, M.W., Sun, K., ThorneLyman, A.L., Moench-Pfanner, R., Akhter, N., Kraemer, K., \& Semba, R.D., 2009. Higher Household Expenditure on Animal-source and Nongrain Foods Lowers the Risk of 
Stunting Among Children 0-59 Months Old in Indonesia: Implications of Rising Food Prices. The Journal of Nutrition, 140(1), pp.195-200.

Schwarzenberg, S.J., Georgieff, M.K., \& AAP Committee On Nutrition., 2018. Advocacy for Improving Nutrition in the First 1000 Days to Support Childhood Development and Adult Health. Pediatrics, 141(2), pp.110.

Semba, R.D., Pee, S.D., Sun, K., Sari, M., Akhter, N., \& Bloem, M.W., 2008. Effect of Parental Education on Risk of Child Stunting in Indonesia and Bangladesh: A Cross-Sectional Study. Lancet, 371(7), pp.322-328.

Simbolon, D., Suryani, D., \& Yorita, E., 2019. Prediction Model and Scoring System in Prevention and Control of Stunting Problems in Under Five-Year-Olds in Indonesia. Jurnal Kesehatan Masyarakat, 15(2), pp.160-170.

Squires, J., \& Bricker, D., 2009. Ages \& Stages Questionnaires: A Parent-Completed Child Monitoring System. Baltimore: Paul H. Brookes Publishing.

Srinivasan, C.S., Zanello, G., \& Shankar, B., 2013. Rural-urban Disparities in Child Nutrition in Bangladesh and Nepal. BMC Public Health,
13(581) pp.1-15.

Taguri, A.E., Betilmal, I., Mahmud, S.M., Ahmed, A.M., Goulet, O., Pilar, G., \& Hercberg, S., 2009. Risk Factors for Stunting Among Under-Fives in Libya. Public Health Nutr, 12(8), pp.1141-1149.

UNICEF,, 2018. Levels and Trends in Child Malnutrition: Key Findings of the 2018. Geneva: World Health Organization Press.

Venetsanou, F., \& Kambas, A., 2009. Environmental Factors Affecting Preschooler's Motor Development. Early Childhood Education Journal, 37(4), pp.319-327.

Victora, C.G., Adair, L., Fall, C., Hallal, P.C., Martorell, R., Richter, L., \& Sachdev, H.S., 2008. Maternal and Child Undernutrition: Consequences for Adult Health and Human Capital. Lancet, 371(9609), pp.340-357.

WHO., 2006. WHO Child Growth Standards: Length/height-for-age, Weight-for-age, Weight-for-length, Weight-for-height, and Body Mass Index-for-age: Methods and Development. Geneva: World Health Organization Press.

WHO., 2014. Global Nutrition Targets 2025: Stunting Policy Brief. Geneva: World Health Organization Press. 